\title{
卵巣摘出ラットの脂肪蓄積に及ばすジンゲロンの影響
}

\author{
韓 立坤, ${ }^{*}, a$ 森本千恵, $b$ 鄭 毅男, $c$ 李 偉, ${ }^{c}$ \\ 浅見悦子, ${ }^{a}$ 奥田拓道, ${ }^{d}$ 齋藤雅人 ${ }^{a}$
}

\section{Effects of Zingerone on Fat Storage in Ovariectomized Rats}

\author{
Li-Kun Han, ${ }^{*}, a$ Chie Morimoto, ${ }^{b}$ Yi-Nan Zheng, ${ }^{c}$ Wei LI, ${ }^{c}$ \\ Etsuko AsAmi, ${ }^{a}$ Hiromichi OKUDA, ${ }^{d}$ and Masato SAITO ${ }^{a}$ \\ ${ }^{a} R \& D$ Laboratory, Kracie Holdings Ltd., 3-20-20 Kaigan, Minato-ku, Tokyo 108-8080, Japan, ${ }^{b}$ Faculty of \\ Pharmacy, Yasuda Women's University, Yasuhigashi, Asaminami-ku, Hiroshima 731-0153, Japan, \\ 'Department of Chinese Material Medicine, Chinese Material Medicine College of Jilin Agricultural \\ University, Changchun City, Jilin 130118, China, and ${ }^{d}$ Professor Emeritus, Ehime University \\ School of Medicine, Shitsukawa, Toon City, Ehime 791-0295, Japan
}

(Received May 29, 2007; Accepted May 9, 2008; Published online June 11, 2008)

\begin{abstract}
We reported that ginger prevented obesity in mice fed a high-fat diet in previous study. In this experiment, we examined the effects of zingerone, the major pungent component of ginger on fat storage in ovariectomized (Ovx) rats. Oral administration of $170 \mathrm{mg} / \mathrm{kg}$ zingerone significantly reduced body weight and the final parametrail adipose tissue weight in ovariectomized rats. Blood glucose levels after oral administration of glucose were lower in zingerone-treated Ovx-rats than in the Ovx-rats (control). Basal lipolysis in zingerone-treated Ovx-rats was increased compared with that in the Ovx-rats. Zingerone significantly increased norepinephrine-induced lipolysis associated with the translocation of hormone-sensitive lipase (HSL) from the cytosol to lipid droplets in adipocytes. These results indicate that zingerone may prevent the fat storage through increasing norepinephrine-induced lipolysis in adipocytes.
\end{abstract}

Key words__ zingerone; basal lipolysis; norepinephrine; hormone-sensitive lipase; ovariectomized rat

\section{は じめに}

閉経後の女性に肥満が多発することはよく知られ ている，その原因の 1 つとして，卵胞ホルモンの消 退が考えられている，以前われわれは，卵胞ホルモ ンと肥満の関係を研究し, 卵胞ホルモンの分泌が, 脂肪合成に係わるとされているリポ蛋白リパーゼ活 性と脂肪分解活性の変動に大きく係わっていること を報告した. ${ }^{1)} こ の$ 報告では，卵胞ホルモンはノル エピネフリンによる脂肪分解の促進作用を有してお り，閉経によってこのホルモンの働きがなくなり体 内に脂肪が蓄積され易い状態に陥るため肥満になり 易いことを示唆している。したがって，卵胞ホルモ ン分泌の少ない閉経後や排卵後には肥満し易くなる ため，この肥満傾向を阻止するには脂肪分解を高め

aクラシエホールディングス陎 $\mathrm{R} \& \mathrm{D}$ 総括部， $b$ 安田女 子大学薬学部薬学科, $c$ 吉林農業大学中薬材学院, $d$ 愛 媛大学名誉教授

*e-mail:r.han@khp.kracie.co.jp
る必要がある。

ジンゲロンはショウガの辛味成分の一種であり, その構造式は抗肥満作用を持つことが知られている カプサイシンと構造式がよく似ている（Fig. 1). 近年, 辛味食品（唐辛子，マスタード及びガーリッ ク）摂取によってエネルギー代謝が充進し熱産生が 増加すること，及びその作用発現には交感神経系を 介して副腎から分泌されるエピネフリン並びに褐色 脂肪組織が関与していることが報告されている. ${ }^{21}$ また最近われわれは，ジンゲロンやカプサイシンと よく似た構造式を持つ物質でラズベリーの香気成分 の 1 つであるラズベリーケトンが, 脂肪細胞におけ るノルエピネフリンによる脂肪分解作用を増強し, 抗肥満作用を示すことを明らかにした. ${ }^{3)}$ さらに前 報ではわれわれは高脂肪食誘発肥満マウスに対する ショウガの抗肥満作用を報告した. ${ }^{4)}$ 最近，われわ れはジンゲロンが脂肪細胞におけるノルエピネフリ ンによる脂肪分解作用を増強することを見い出した ことから閉経後更年期のモデルである卵巣摘出手術 
Zingerone<smiles>CC(=O)CCc1ccc(O)c(O)c1</smiles>

\section{Raspberry ketone}

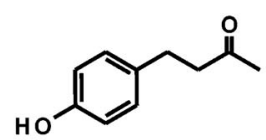

Capsaicin

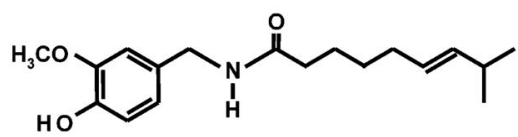

Fig. 1. Structural Formula of Zingerone, Raspberry Ketone and Capsaicin

を施したラットに脂肪分解促進作用のあるジンゲロ ンを経口投与し，その投与効果を検討することにし た．また，ジンゲロンの作用機序を検討するために 脂肪細胞を用いてホルモン感性リパーゼ活性に対す る影響も検討した。

\section{実験材料及び実験方法}

1. 実験動物及び飼料 5 週齢 Kud:Wistar 系 雄性ラット [九動(侏), 熊本] を 1 週間予備飼育した のち, 卵巣摘出手術を行い実験に供した。 1 群 5 匹 の計 4 群に分け 3 群は腹部より卵巣を摘出し 1 群は 偽手術を施した。卵巣摘出後 3 日間の観察飼育のの ち, 卵巣摘出の 3 群は水投与群 $(\mathrm{Ovx}-\mathrm{c}), 62.5 \mathrm{mg} /$ $\mathrm{kg}$ ジンゲロン投与群（Ovx-z 62.5）及び $170 \mathrm{mg} / \mathrm{kg}$ ジンゲロン投与群（Ovx-z 170）の 3 群に分けた. 純水及びジンゲロンの投与は 1 日 2 回（投与時間： 朝 $10 ： 00$, 夕方 $16: 00), 1 \mathrm{ml}$ を 72 日間経口投与 した。偽手術（Sham-c）群については，Ovx-c 群 と同様に 1 日 2 回，水 $1 \mathrm{ml}$ を経口投与した。飼育 期間中，飼料は固形飼育用飼料 $\mathrm{CE}-2$ を，水は水道 水を自由摂取させた。飼料摂取量は毎週 1 回測定 し，そのつど飼料を交換した。体重も 1 週間毎に測 定した。また，飼育は室温 $23 \pm 1^{\circ} \mathrm{C}$ ，湿度 $55 \pm 5 \%$, 12 時間毎の明暗サイクル（明期 : 7 ：00 am-暗期 : $7: 00 \mathrm{pm} ）$ の環境で行った。なお，本実験は愛媛 大学医学部制定の動物実験指針に基づく動物実験管 理委員会の承認の下に行われた。

2. 卵巣摘出ラットの体重, 摂食量及び子宮傍脂 肪組織重量に及ばす影響卵巣摘出手術を行った のち，3 日間予備飼育して平均体重が等しくなるよ う 1 群 5 匹の 3 群に分け 72 日間飼育した。飼育期
間中，体重と摂食量は週 1 回測定し，飼料は測定毎 に新しく入れ替えた。平均摂取エネルギーは飼育期 間中の平均摂食量から算出した。

飼育終了後，ラットをエーテル麻酔下で開腹し， 腹部下大静脈より採血した。 その後, 速やかに子宮 傍脂肪組織及び小腸を摘出し重量を測定した。血液 は $4^{\circ} \mathrm{C}, 3000 \mathrm{rpm}$ で 10 分間遠心分離し血清を得 た。 小腸は $200 \mathrm{mM}$ リン酸緩衝液（pH 7.0）で洗浄

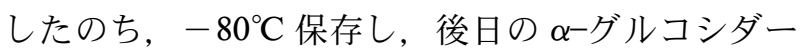
ゼ活性の分析に供した。

\section{3. 卵巣摘出ラットの基礎脂肪分解能に及ぼす影} 響基礎分解能とは，エピネフリンやノルエピネ フリンなどの脂肪分解促進ホルモン非存在下での脂 肪分解能を示す。採取した子宮傍脂肪組織の血管な どを除去し，脂肪組織切片を調製した． $0.25 \mathrm{ml}$ の $2.5 \%$ 牛血清アルブミン溶液に $0.05 \mathrm{ml}$ の脂肪組織 切片を加え $37^{\circ} \mathrm{C}$ で 1 時間反応したのち遊離した脂 肪酸をZapf の方法5)で測定した。

4. 脂肪細胞におけるノルエピネフリンによる脂 肪分解に及ばす影響 6 週齢の Wistar 系雄性ラ ットを頸椎脱臼後, 直ちに副睪丸脂肪組織を採取し, Rodbell の方法6) に準じて脂肪細胞を調製した．脂 肪細胞 $0.05 \mathrm{ml}$ に $2.5 \%$ 牛血清アルブミンを含む Hanks 緩衝液（pH 7.4）を $0.2 \mathrm{ml}$, 反応液中の最 終濃度が $0.01 \mu \mathrm{g} / \mathrm{ml}$ になるように調製したノルエ ピネフリンを $0.025 \mathrm{ml}$ 及び種々の濃度のジンゲロ ンを $0.025 \mathrm{ml}$ 加え $37^{\circ} \mathrm{C}$ で 1 時間反応したのち, Zapf の方法5) 用いて遊離脂肪酸を測定した。一 方，脂肪細胞の生存率に対するジンゲロンの影響を LDH C-II テストワコー（和光純薬工業製）にて測 定した.

5. 脂肪細胞におけるノルエピネフリンによる脂 肪分解及びホルモン感性リパーゼ（HSL）の局在に 及ぼす影響＼cjkstart脂肪細胞に $2.5 \%$ 牛血清アルブミン を含む Hanks 緩衝液 $0.4 \mathrm{ml}$, ノルエピネフリン 0.05 $\mathrm{ml}$ 及びジンゲロン $0.05 \mathrm{ml}$ を加え $37^{\circ} \mathrm{C}$ で 1 時間反 応したのち, 室温で $100 \times \mathrm{g}, 30$ 秒遠心分離し, 脂肪

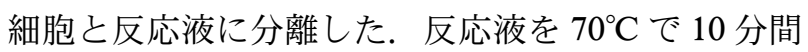
加温したのち， $0.05 \mathrm{ml}$ を採取し酵素法にて遊離グ リセロールを測定した。 一方, 残った脂肪細胞に緩 衝液 A $(25$ mM Tris- $\mathrm{HCl} ， \mathrm{pH} 7.4 ， 254$ mM サッカ ロース, $1 \mathrm{~mm}$ EDTA, $0.1 \mathrm{mM}$ ベンズアミジン, 20 $\mu \mathrm{M}$ ロイペプチン及び $2 \mathrm{mg} / \mathrm{ml}$ トリプシン阻害剤を 
含む）を $0.45 \mathrm{ml}$ 加えてホモジナイズし， $2500 \times \mathrm{g}$, $4^{\circ} \mathrm{C}$ で 10 分間遠心分離後，上清を抜き取り，残った 脂肪層に $20 \%$ SDS を含む Laemmli sample solution を加えよくかく汼した。抜き取った上清には $1 \%$ SDS を含む Laemmli sample solution を加え同様に よくかく拌した。これら sample solution は 5 分間 煮沸したのち，SDS-ポリアクリルアミドゲル電気 泳動（ゲル濃度 8\%）及び Western blotting を行い, HSL 抗体を用いてタンパクを検出した. なお, HSL 抗体は, ラットの脂肪細胞 HSL のアミノ酸 326 番 目から 341 番目のペプチド GPRLELRPRPQQAPPS を合成し，これをウサギに投与し抗血清として作成 した。

6. 統計処理 測定值は平均值士標準誤差で表 した. 2 群間の有意差検定は対応なしの Student's $t$ 検定を用いて行った。多群間の有意差検定は Dunnett 検定によって行った。計算には SPSS 14.0Jソ フト $[$ エス・ビー・エス・エス侏］を用いた。す心゙ ての検定において $p<0.05$ の場合を有意差ありと判 断した.

\section{結果}

1. 脂肪分解能の比較 ジンゲロンの構造が力 プサイシン及びラズベリーケトンによく似ているこ とから，脂肪細胞における脂肪分解に対する影響を 比較した（Fig. 1). Figure 2 に示すように，脂肪細 胞より単離した脂肪細胞に 0.05 及び $0.1 \mathrm{mg} / \mathrm{ml}$ の ノルエピネフリンを作用させると脂肪分解が著明に 六進した。しかし， $0.01 \mathrm{mg} / \mathrm{ml}$ では著しい脂肪分 解の充進は認められなかった。一方それぞれ $1 \mathrm{mM}$ のジンゲロン，カプサイシン及びラズベリーケトン を単独で脂肪細胞に作用させると，カプサイシン及 びラズベリーケトンの単独添加では脂肪分解の著明 な克進が認められなかったが，ジンゲロンの単独添 加では有意な脂肪分解促進作用が認められた。さら に，脂肪分解の克進が認められなかった $0.01 \mathrm{mg} /$ $\mathrm{ml}$ のノルエピネフリンにそれぞれ $1 \mathrm{~mm}$ のジンゲ
ロン，カプサイシン及びラズベリーケトンを添加す ると，いずれもノルエピネフリンの脂肪分解促進作 用を増強し，特にジンゲロンが最も強く増強した。

2. 摂食量, 体重及び子宮傍脂肪組織重量 飼 育期間中の平均摂取エネルギーを Table 1 に示した. Sham-c 群に比べて Ovx-c 群では有意な平均摂取工 ネルギーの増加が認められた。Ovx-c 群に比べて Ovx-z $62.5 \mathrm{mg} / \mathrm{kg}$ 及び Ovx-z $170 \mathrm{mg} / \mathrm{kg}$ 群では有 意な平均摂取エネルギーの低下が認められなかつ た。育期間中のラットの体重を Fig. 3 に示した. Sham-c 群に比べて Ovx-c 群では有意な体重増加が 認められた。Ovx-c 群に比べて Ovx-z $62.5 \mathrm{mg} / \mathrm{kg}$ 群では有意な体重低下が認められなかったが, Ovx-z $170 \mathrm{mg} / \mathrm{kg}$ 群では飼育 60 日目以後に有意な 体重低下が認められた。宮傍脂肪組織重量につい ては, Fig. 3 に示すように Ovx-c 群では Sham-c 群 に比べて有意な増加が認められ，Ovx-c 群の体重増 加原因の 1 つとして脂肪組織量の増加が考えられる.

Ovx-z $62.5 \mathrm{mg} / \mathrm{kg}$ 及び Ovx-z $170 \mathrm{mg} / \mathrm{kg}$ 群では

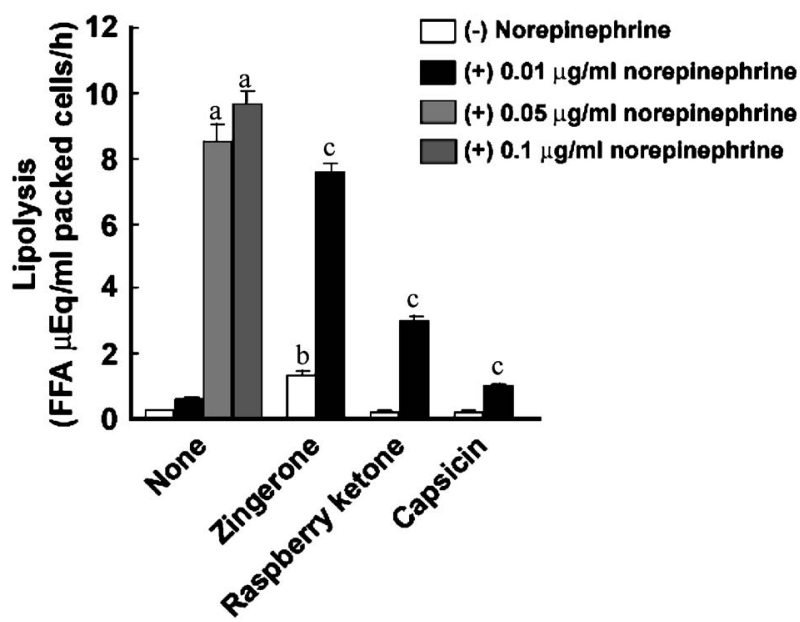

Fig. 2. Effects of Zingerone, Raspberry Ketone and Capsaicin on Lipolysis in Rat Epididymal Fat Cells

Lipolysis was expressed as $\mu$ Eq FFA released per ml packed fat cells per h. Values are means \pm S.E. in each group. $a=p<0.05$, vs. $(-)$ norepinephrine by student's $t$ test. $\mathrm{b}=p<0.05$, vs. (-) norepinephrine by student's $t$ test. $\mathrm{c}=p<0.05$, vs. ( - ) $0.01 \mu \mathrm{g} / \mathrm{ml}$ norepinephrine by student's $t$ test.

Table 1. Effects of Zingerone on Food Intake

\begin{tabular}{ccccc}
\hline \hline & Sham & Ovx & Ovx-z62.5 & Ovx-z170 \\
\hline Energy intake $(\mathrm{kcal} / \mathrm{d} / \mathrm{rat})$ & $48.92 \pm 2.05^{*}$ & $58.55 \pm 2.10$ & $60.64 \pm 4.71$ & $56.77 \pm 4.97$ \\
\hline
\end{tabular}

Results are expressed as mean \pm S.E. ${ }^{*} p<0.05$, vs. Ovx-group by Dunnett test. 


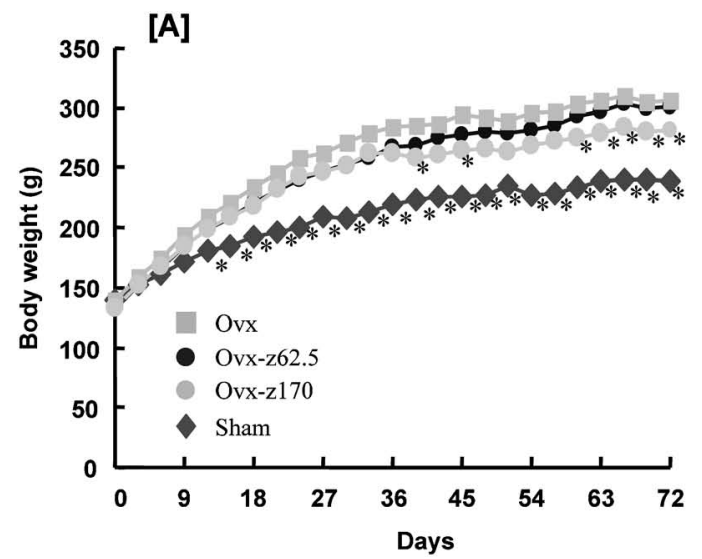

[B]

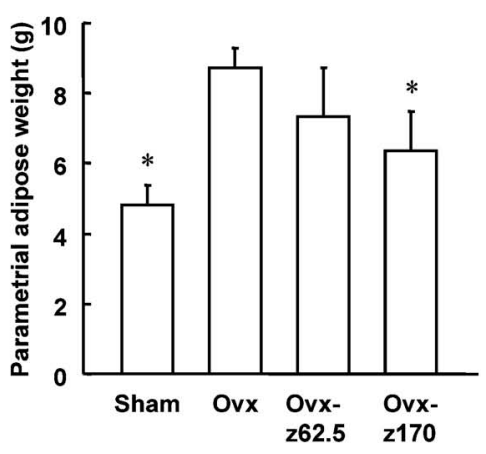

Fig. 3. Effect of Zingerone on Body Weight [A] and Parametrial Adipose Tissue Weight [B] in Ovariectomized Rats Values are means \pm S.E. in each group. ${ }^{*} p<0.05$, vs. Ovx-group by Dunnett test.

Table 2. Effects of Zingerone on Sucrase and Maltase Activities in Rat Intestinal Mucosa at 72 Days after Sham-operation or Ovariectomy

\begin{tabular}{lcrrr}
\hline \hline & \multicolumn{1}{c}{ Sham } & \multicolumn{1}{c}{ Ovx } & \multicolumn{1}{c}{ Ovx-z62.5 } & \multicolumn{1}{c}{ Ovx-z170 } \\
\hline Small intestine weight $(\mathrm{g})$ & $4.24 \pm 0.62$ & $4.88 \pm 0.88$ & $4.10 \pm 0.60$ & $4.37 \pm 0.87$ \\
Sucrase $(\mu$ moles/h/mg protein) & $4.14 \pm 0.22^{*}$ & $5.75 \pm 0.16$ & $5.21 \pm 0.13$ & $4.81 \pm 0.34$ \\
Maltase $(\mu$ moles $/ \mathrm{h} / \mathrm{mg}$ protein) & $17.38 \pm 1.51^{*}$ & $29.62 \pm 1.25$ & $27.98 \pm 2.69$ & $25.31 \pm 3.83$ \\
\hline
\end{tabular}

Results are expressed as mean \pm S.E. of 5 rats. ${ }^{*} p<0.05$, vs. Ovx-group by Dunnett test.

Ovx-c 群に比ベてジンゲロンの投与量依存的に子宮 傍脂肪組織重量が低下傾向を示し, Ovx-z $170 \mathrm{mg} /$ $\mathrm{kg}$ 群では Ovx-c 群に対して有意な低下が認められ た. 血中 GOT 及び GPT の值について測定したと ころ, GOT (IU/1) の值については, Sham-c 群, Ovx-c 群, Ovx-z $62.5 \mathrm{mg} / \mathrm{kg}$ 及び Ovx-z $170 \mathrm{mg} / \mathrm{kg}$ 群の GOT の值がそれぞれ $105.0 \pm 11.8,118.0 \pm 14$, $121.0 \pm 16.5,110 \pm 21.1$ であった. GPT (IU/1) の 値については, Sham-c 群, Ovx-c 群, Ovx-z 62.5 $\mathrm{mg} / \mathrm{kg}$ 及び Ovx-z $170 \mathrm{mg} / \mathrm{kg}$ 群の GPT の值がそれ ぞれ $16.5 \pm 1.1,17.5 \pm 3.4,18.1 \pm 1.5,17.7 \pm 2.3$ であ つた. Sham-c 及び Ovx-c 群に比べてジンゲロン投 与による血中の GOT, GPT 值には有意な変化が認 められなかった。

\section{3. 小腸及び小腸粘膜由来酵素活性 Table 2} に示すように小腸重量については, 各群の間におい て有意な変化が認められなかった. 小腸粘膜由来酵 素であるスクラーゼ活性及びマルターゼ活性につい ては, Ovx-c 群では Sham-c 群に比べて有意な上昇 が認められた。Ovx-z $62.5 \mathrm{mg} / \mathrm{kg}$ 及び Ovx-z 170 $\mathrm{mg} / \mathrm{kg}$ 群では, Ovx-c 群に比べてスクラーゼ活性及 びマルターゼ活性は低下傾向がみられたが有意な変
化は認められなかった。

4. 基礎脂肪分解能 Table 3 に基礎脂肪分解 能を示した. Sham-c 群に比べて，Ovx-c 群では基 礎脂肪分解能が上昇したが有意な差が認められなか つた。一方 Ovx-z $62.5 \mathrm{mg} / \mathrm{kg}$ 及び Ovx-z $170 \mathrm{mg} /$ $\mathrm{kg}$ 群では, ジンゲロンの投与量依存的に基礎脂肪 分解能を高めた。

5. 飼育期間中グルコース負荷後ラットの血糖値 の変化 一晚絶食した各群のラットに $0.8 \mathrm{mg} / \mathrm{ml}$ のグルコース溶液 $1 \mathrm{ml}$ を経口投与した血糖值の変 化を Fig. 4 に示した. グルコース負荷後の血糖值 は, Ovx-c 群においては Sham-c 群に比べて高值を 示した。 Ovx-z $62.5 \mathrm{mg} / \mathrm{kg}$ 及び Ovx-z $170 \mathrm{mg} / \mathrm{kg}$ 群においては, Sham-c 群と同様な血糖值推移を示 した.

6. 脂肪細胞におけるノルエピネフリンの脂肪分 解に及ぼす影響 Figure 5 に示すように, ジンゲ ロン単独では $10^{-6} \sim 10^{-4} \mathrm{M}$ の濃度で脂肪分解の促 進はほとんどみられなかったが, $10^{-3} \mathrm{M}$ の濃度で は脂肪分解を促進した。 ノルエピネフリン存在下で は， $10^{-4} \mathrm{M}$ のジンゲロン添加でノルエピネフリン の脂肪分解作用を有意に増強した。また反応後の反 
Table 3. Effects of Zingerone on Basal Lipolysis in Fat Cells Isolated from Ovariectomized Rats

\begin{tabular}{ccccc}
\hline \hline & Sham & Ovx & Ovx-z62.5 & Ovx-z170 \\
\hline Basal lipolysis $($ FFA $\mu \mathrm{mol} / \mathrm{h} / \mathrm{g})$ & $0.095 \pm 0.021$ & $0.102 \pm 0.023$ & $0.124 \pm 0.017$ & $0.149 \pm 0.055^{*}$ \\
\hline
\end{tabular}

Results are expressed as mean \pm S.E. of 5 rats. ${ }^{*} p<0.05$, vs. Ovx-group by Dunnett test.

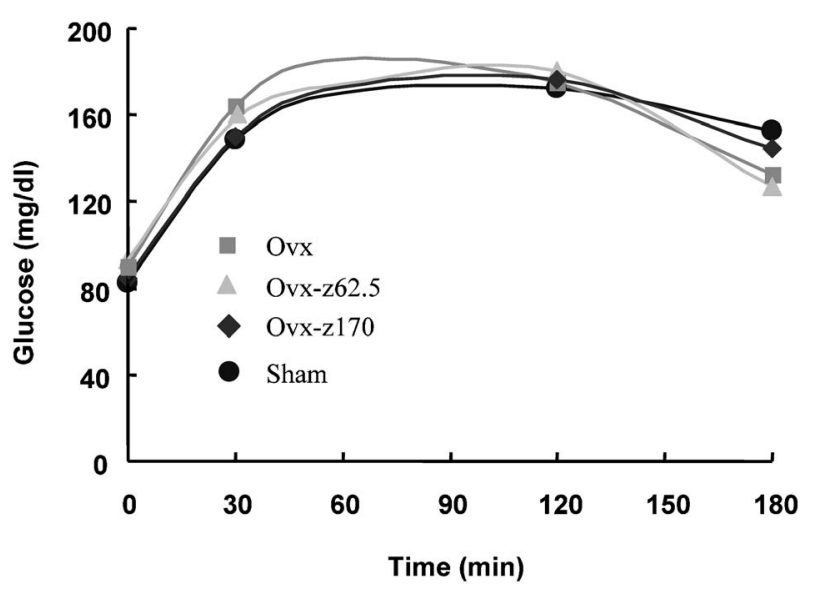

Fig. 4. Effect of Zingerone on Blood Glucose after Oral Administration of Glucose in Ovariectomized Rats

Values are means \pm S.E. in each group.

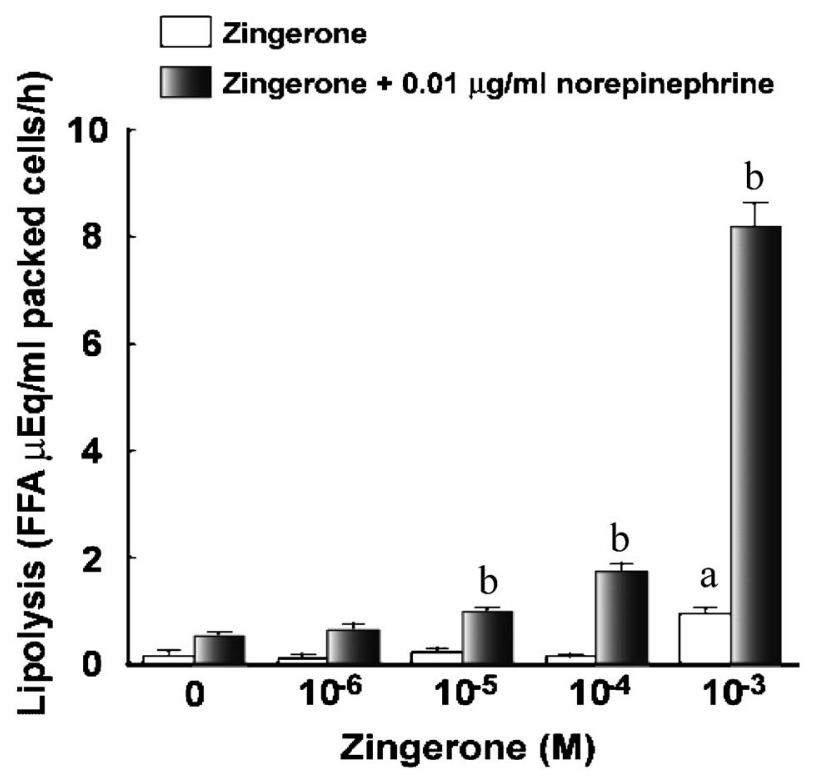

Fig. 5. Effect of Various Concentrations of Zingerone on Lipolysis in Rat Epididymal Fat Cells

Lipolysis was expressed as $\mu$ Eq FFA released per ml packed fat cells per h. Values are means \pm S.E. in each group. $\mathrm{a}=p<0.05$, vs. zingerone $(0 \mathrm{M})$ by student's $t$ test. $\mathrm{b}=p<0.05$, vs. $0.01 \mu \mathrm{g} / \mathrm{ml}$ norepinephrine by student's $t$ test.

応液を採取して LDH 活性を測定したところ，無添 加時の $\mathrm{LDH}$ 值を $100 \%$ とし，10 $10^{-6}, 10^{-5}, 10^{-4}$ 及 び $10^{-3} \mathrm{M}$ ジンゲロンを添加したときの LDH 值は
それぞれ 100.5 $\pm 3.1,97.2 \pm 5.7,109.2 \pm 4.5,103.5 \pm$ 6.3 であった。いずれも有意な変化が認められなか つた.

7. 脂肪細胞におけるノルエピネフリンの脂肪分 解及びホルモン感性リパーゼの局在に及ばす影響 つぎに，ジンゲロンの脂肪分解増強作用とホルモ ン感性リパーゼ（HSL）の局在の関係を検討した.

Figure 6 に示すように，ジンゲロンがノルエピネフ リンの脂肪分解作用を増強するに従って, HSL の 細胞質から脂肪層への移行が認められた。また，結 果には示していないが，ホルモン感性リパーゼ活性 及び総タンパク量には全く影響を及ぼさなかった。

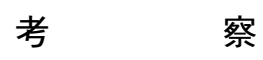

今回の結果は，ジンゲロンが摂取エネルギーを低 下させずに脂肪分解促進作用を高めることを通じ て, 卵巣摘出ラットの体重及び脂肪組織重量の増加 を抑制し，肥満を緩和したことを示した，卵巣を摘 出することによって，マウス及びラットの摂食量の 増加や自発運動の低下を引き起こすことが報告され ている. ${ }^{7)}$ また最近では，卵巣摘出ラットにおいて は，小腸粘膜由来酵素活性が増加することが報告さ れている。本研究では, 卵巣摘出ラットの平均摂 取エネルギーが有意に増加したことが認められた。 また，小腸粘膜由来酵素の活性が有意に高いことも 認められた。一方，ジンゲロン投与では，平均摂取 エネルギーや小腸粘膜由来酵素の活性に対していず れも有意な影響が認められなかった。したがって， 本研究で認められたジンゲロンの体重及び脂肪組織 重量の増加抑制作用は，摂取エネルギー低下作用及 び小腸粘膜由来酵素活性の抑制作用以外の作用機序 を通じて発揮したことが示唆された．最近，石見ら は動物実験においてジンゲロンの酸素消費の増加並 びに呼吸商の低下に対して有意な効果を持つことを 明らかにした. ${ }^{9)}$ すなわちジンゲロンには脂肪分解 を促進し，同時にエネルギー消費を高める作用を持 つことを示している. ${ }^{9)}$ 今回の実験では，ジンゲロ 
[A]

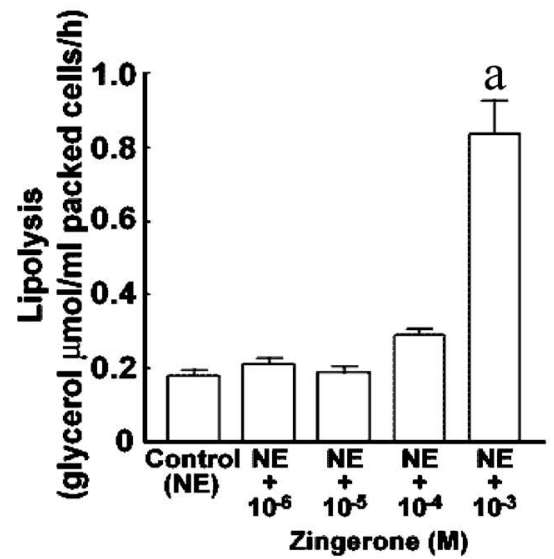

[B]
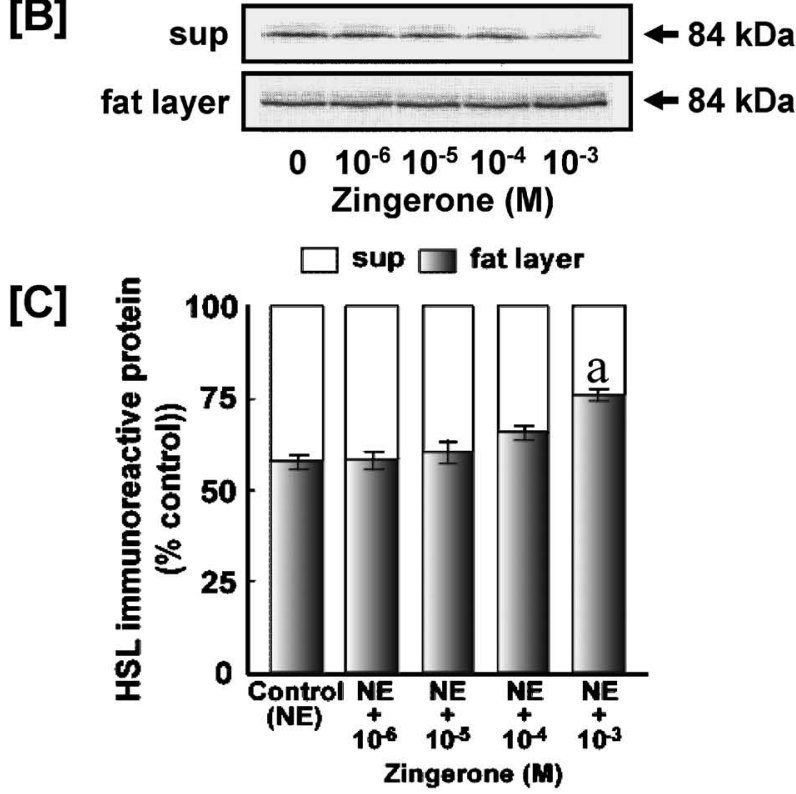

Fig. 6. Effect of Various Concentrations of Zingerone on Lipolysis [A] and Localization of Hormone-sensitive Lipase (HSL) $[\mathrm{B}],[\mathrm{C}]$ in Rat Epididymal Fat Cells

Values are means \pm S.E. in each group. $[\mathrm{A}]$ : Lipolysis was expressed as $\mu$ mol glycerol released per ml packed fat cells per $\mathrm{h} . \mathrm{a}=p<0.05$, vs. control (NE) by student's $t$ test. [B]: A representative immunoblot showing the HSL protein levels of norepinephrine- and zingerone-treated cells. [C]: HSL immunoreactive protein levels of the supernatant and fat layer tabulated as the percentage fraction of the density detected by enhanced chemifluorescence determined using a FluorImager, Fluorescence Imaging Analyzer (Amersham Pharmacia Biotech UK Ltd. Bucks UK) . a $=p<0.05$, vs.control (NE) by student's $t$ test.

ン投与によって基礎脂肪分解能を高めたことが認め られた。脂肪細胞にエピネフリンやノルエピネフリ ンなどのホルモンを作用させると脂肪分解が促進す るが，それらの脂肪分解促進剂を作用させない場合 の自発的に行われる脂肪分解，すなわち基礎脂肪分 解能は, 肥満になり脂肪細胞が拡大するにつれて増 加する. ${ }^{10)}$ その原因の 1 つとして, 脂肪細胞が拡大 する。.すなわち脂肪細胞中の大部分を占める油滴が
拡大すると, 油滴表面にあるレシチン量がその拡大 によって相対的に減少し, 油滴表面にレシチンの隙 間が生じ，HSL が細胞内の油滴と接触し易くなり 脂肪分解を引き起こすことが考えられる。これまで に，われわれは脂肪分解促進作用のあるカフェイン やコレウスなどの卵巣摘出ラットにおける有用性を 報告し, 卵巣摘出ラットにおけるカフェインやコレ ウスの脂肪蓄積抑制作用は，基礎脂肪分解能を高め たことによることを示唆した. ${ }^{11,12)}$ 本研究におい て，ジンゲロン投与によって基礎脂肪分解能が高ま つたことは，生体内に取り込まれたジンゲロンが HSL と細胞内の油滴との接触を高めたことによる ものと考えられる。 そこで，このジンゲロンの脂肪 分解増強作用のメカニズムを検討するために，ラッ 卜副睪丸脂肪組織より脂肪細胞を調製し，脂肪細胞 におけるノルエピネフリン存在下又は非存在下での ジンゲロンの脂肪分解作用と HSL の局在を検討し た。その結果，ジンゲロン単独で $10^{-3} \mathrm{M}$ という濃 度で脂肪分解を促進したが，ノルエピネフリンと併 用するとさらに低い濃度 $10^{-4} \mathrm{M}$ で脂肪分解を促進 した。そのときの HSL の局在は，Cytosol から脂 肪層へ移行していることが明らかになった（Fig. 5)。また，結果には示していないが，ホルモン感性 リパーゼ活性及び総タンパク量には全く影響を及ぼ さなかった．したがって，ジンゲロンの脂肪分解増 強作用は脂肪細胞における HSL の活性化によるも のではなく，HSL の脂肪滴への結合の促進による ものと示唆された。一方, in vivo で得られたジン ゲロンの効果が in vitro のそれに比べて弱く，これ は恐らく in vitro においてジンゲロンが直接脂肪細 胞に作用しており，in vivo では腸管吸収及び血中 濃度，他の因子（インスリンなど）などの影響も考 えられる，今後，ジンゲロンの腸管吸収効率や血中 濃度などについて詳細な検討を行っていく必要があ る.

今回，閉経後更年期のモデル動物である卵巣摘出 ラットにおいて，ジンゲロンの脂肪蓄積抑制作用が 認められ，ジンゲロンを摂取することによって女性 ホルモンの低下による肥満を改善する可能性が示さ れた。 今後，ヒトにおけるジンゲロンの有用性につ いてさらに検討していきたい. 


\section{REFERENCES}

1) Yamaguchi M., Katoh S., Morimoto C., Sakayama K., Shiosaka T., Masuno H., Okuda H., Int. J. Obes. Relat. Metab. Disord., 26, 610-617 (2002).

2) Iwai K., Watanabe T., "Red Peppers-Science of Pungency," Saiwaishobou Co., Ltd., Tokyo, 2000, pp. 157-167.

3) Morimoto C., Satoh Y., Hara M., Inoue S., Tsujita T., Okuda H., Life Sci., 77, 194-204 (2005).

4) Han L.-K., Gong X.-J., Kawano S., Saito M., Kimura Y., Okuda H., Yakugaku Zasshi, 125, 213-217 (2005).

5) Zapf J., Schoenle E., Waldvoge M., Sand M., Foresch E. R., Eur. J. Biochem., 133, 605-609 (1981).
6) Rodbell M., J. Biol. Chem., 239, 375-380 (1964).

7) Mook D. G., Kenney N. J., Roberts S., Nussbaum A. I., Rodier 3rd. W. I., J. Comp. Physiol., Psychol., 81(2), 198-211 (1972).

8) Ishiguro S., Harimoto Y., Horie K., Takahashi S., Kato Y., Yamada K., Moriuchi S., Jap. Women's Univ. J., 32, 25-27 (1985) .

9) Iwami M., Terada S., Sunahara M., Shimooka R., Shimazu T., J. Jpn. Soc. Nutr. Food Sci., 56, 159-165 (2003).

10) Morimoto C., Tsujita T., Okuda H., J. Lipid Res., 38, 957-962 (1998).

11) Han L.-K., Kai F., Okuda H., Yakugaku Zasshi, 124, 841-846 (2004).

12) Han L.-K., Morimoto C., Yu R.-H., Okuda H., Yakugaku Zasshi, 125, 449-453 (2005) . 